\title{
ETHICAL BEHAVIOR AND ORGANIZATIONAL INNOVATION: ANALYSIS OF SMALL AND MEDIUM-SIZED ENTERPRISES IN LATVIA
}

\author{
Madara APSALONE ${ }^{1}$, Ricardo Martín FLORES ${ }^{2}$ \\ ${ }^{1}$ University of Latvia, Riga, Latvia \\ ${ }^{2}$ Riga Business School, Riga, Latvia \\ Corresponding author e-mail: madara.apsalone@gmail.com
}

\begin{abstract}
Innovations can provide small and medium-sized enterprises (SMEs) a significant competitive advantage considering the ambiguous business environment. SMEs may face lower capacity and more constrained funding for long-term investments, however, understanding innovation in a broader sense and looking into organizational structures, behaviors and processes, SMEs have an opportunity to become more competitive. This study analyzes the impact of ethical behavior as a part of an organizational culture on organizational innovation performance in SMEs. Six hundred SMEs in Latvia were surveyed to assess whether employees follow the principles of business ethics in their work and what is the organizational innovation performance in these enterprises. We found that more ethical behavior leads to better organizational innovation performance, and that the size of enterprise is the most significant factor affecting this relationship. The study proposes insights that contribute to theoretical and practical discussions on fostering small businesses innovation in small economies.
\end{abstract}

Keywords: Competitiveness, ethical behavior, organizational culture, organizational innovation, small and medium-sized enterprises.

JEL Classification: M14, O30

\section{INTRODUCTION}

SMEs play an important role in many European economies, thus their ability to innovate is vital for welfare and economic growth. Innovative SMEs could differentiate themselves from the competition (Porter, 1980), yet the share of innovative SMEs in Europe is very low - according to the Eurostat, only $48 \%$ of SMEs were innovative compared to $78.1 \%$ of large enterprises (Eurostat, 2017). Innovation process is complex and includes substantial ambiguity and risk (Kline \& Rosenberg, 1986), and SMEs might have more constrained resources for longterm, large-scale innovation projects (Acs \& Audretsch, 1988; Nooteboom, 1994). They might also have less human resources to effectively implement innovations. Considering these aspects, SMEs might have higher relative costs to innovate in comparison to large businesses.

Meanwhile, innovation is not limited to introduction of new products and services. New forms of workplace organization, new managerial concepts, cross- 
functional teams, decentralization of decision making and continuous quality improvement - all can be considered forms of organizational innovation (Schumpeter, 1934; Damanpour, 1987; Womack \& Jones, 1990; OECD-Eurostat, 2005). And SMEs could take advantage of their leaner structures and more entrepreneurial approach (Nooteboom, 1994), when implementing these nontechnological process changes. Thus SMEs could enhance organizational innovations through their internal factors - work practices and attitudes, ethical behavior amongst them.

In times of globalization and increasing importance of corporate social responsibility, companies with a strong business ethics and sound corporate reputation can gain a sustainable competitive advantage. Ethical behavior has several clear advantages - businesses can be more effective, when employees have a clear vision and can take the right actions decisively. Ethical and transparent working methods also help to develop long-term external relations with stakeholders, and can contribute to organization being perceived as an attractive employer. Unethical behavior, on the other hand, can harm businesses in many ways, negatively affecting corporate reputation and creating internal tensions amongst employees, who act ethically, and those, who do not.

This study assesses how ethical behavior affects organizational innovation. The aim of this study is to find out, whether enterprises where employees follow the principles of business ethics in their work demonstrate a better organizational innovation performance. This study develops hypothesis that enterprises, where employees follow the principles of business ethics in their work, have a better organizational innovation performance. This study uses such statistical analysis techniques as normality testing, contingency tables, simple regression through the ordinary least squares method, analysis by factors, Kruskal-Wallis test and Wilcoxon rank sum test.

\section{LITERATURE REVIEW}

\subsection{Ethical Behavior}

Ethics is an intangible concept that can be defined in many diverse ways. The term originated from a Greek word ethikos (Boatright, 1997). Nowadays, ethical behavior can be seen through three conceptually different approaches consequentialist or teleological approach considering the result, nonconsequentialist or deontological approaches considering the intent, and virtue ethics considering the character of the actor (Boatright 1997; Fisher \& Lovell 2009).

According to consequentialist (teleological) ethics, behavior itself is neither ethical nor unethical, however it has a positive or negative result. Decision making is rational and pragmatic - ethical behavior increases the positive outcomes, while unethical behavior reduces them. Thus, one would behave ethically, when considering consequences for everyone directly or indirectly affected by a particular decision or action. 
Non-consequentialist (deontological) approach considers principles irrespectively of outcomes. Thus, ethical behavior is determined through a duty and obligations towards others. A behavior is either fundamentally right or wrong.

Virtue ethics firstly considers values and character of an actor. Following this approach, a good person or organization would behave ethically. Ethical behavior is mainly determined by personal and organizational values. Values, as part of culture, are learned, shared and are specific to a particular group or community (Hofstede, Hofstede \& Minkov, 2010). As values are socially constructed, they depend on the context and change over time. Therefore, perception of what would be an ethical organization, changes over time.

The aforementioned approaches of determining an ethical behavior contradict each other. The first approach considers a completely rational action specific to a particular situation, while the second - fundamental principles that must be adhered to irrespectively of the context. The first two approaches consider action, while virtue ethics - the actor. This approach might explain business ethics the best, as defining certain organizational values could lead to better actions of employees at that organization.

Real-life situations can present several conflicting ethical considerations, thus behavioral ethics assesses the actual behavior considering moral standards. Behavioral ethics explains that moral principles might not remain constant at all times, and that context could affect any particular behavior (Treviño, Weaver \& Reynolds, 2006).

\subsection{Organizational Innovation}

The concept of innovation is very broad. Already in 1934, Joseph Alois Schumpeter listed five forms on innovation in his theory of economic development: an inquiry into profits, capital, credit, interest, and the business cycle - new products, new production methods, new markets, new supply sources and new forms of organization (Schumpeter, 1934). He explained that some innovations are technical, such as new products and new production methods, while others - nontechnical, such as new forms of organization. Therefore, we can consider that the concept of organizational innovation was proposed already in 1934.

Not any new invention is an innovation. Peter Ferdinand Drucker (1985) argued that an invention becomes a resource, when an organization finds and application for it. He suggested seven areas of opportunity, which can drive innovation: unexpected successes and failures, process incongruities, process needs, changes in industry and market structures, industry and market changes, changes in demographics, changes in perception, as well as new knowledge that can be used to develop innovative ideas. Following this approach, innovation can be driven by the organization itself, or by the external environment. Similarly, Gary Hamel explained that innovation can be created through diverse perspectives (Hamel, 2000).

A comprehensive framework for innovation was developed by the Eurostat and the Organization for Economic Co-operation and Development (OECD) in the Oslo Manual. This manual categorizes four types of innovation: product, process, marketing and organizational innovations. Product innovations include new or 
significantly improved products. Process innovation includes new or significantly improved production or delivery methods. Marketing innovations include new marketing methods, significant design or packaging changes, as well as product placement, promotion or pricing. Organizational innovations include new organizational methods in the company's business practices, workplace organization or external relations (OECD-Eurostat, 2005).

Organizational innovation can include such business developments, as using cross-functional teams, job enrichment, decentralization and continuous improvement towards lean production (Womack \& Jones, 1990). These innovations also include new managerial and working concepts and practices (Damanpour, 1987). Organizational innovations can be structural or procedural, as well as interorganizational - taking place beyond an enterprise, and intra-organizational taking place within an enterprise (Armbruster et al., 2008). Organizational innovation can support product and process innovation, as well as directly improve business performance through better efficiency, increased quality and reduced costs (OECD-Eurostat, 2005).

Strong organizational values and ethical behavior can support organizational innovation. As any innovation process and organizational transformation can bring certain complexity and uncertainty, shared ethical norms and values can provide additional guidance for decision-making process. Previous research has confirmed that ethical approach positively affects social innovation (Knut \& Zsolnai, 2014), and ethical behavior can also help to develop and improve external relations with a broad range of business stakeholders. And strong values could be beneficial for innovation in general - for instance, organizations that have a strong value of trust could display better innovation performance, because higher levels of trust could lead to contributing more innovative ideas (Hosmer, 1995).

Based on the literature review, this study develops a hypothesis that enterprises, where employees follow the principles of business ethics in their work, have a better organizational innovation performance.

\section{METHODOLOGY OF RESEARCH}

\subsection{The Questionnaire and the Sample}

We used a structured, closed-ended questionnaire to assess the relationship between ethical behavior and organizational innovation. This questionnaire included various statements about organizational culture and innovation, in this study we used those related to the main research question.

The first part of the questionnaire included statements about organizational values, attitudes and behaviors, amongst them whether employees followed the principles of business ethics in their work. As ethical behavior is a sensitive issue, it might cause social desirability bias. One way to mitigate this bias would be to ask the question more indirectly, thus the question about ethics was asked not about managers themselves, but about employees in their organizations. Statements in the first part were measured using the Likert scale from 1, where the statement was 
completely inapplicable to the enterprise, to 10 , where the statement was fully applicable to the enterprise.

The second part included four statements about organizational innovation whether the enterprise used cross-sectorial teams (company has project teams or working groups that include specialists from different fields), whether it had quality management systems (systems for improving the quality of goods or services), whether it used outsourcing for workplace organization (outsourcing of auxiliary functions), and weather it cooperated with business associations or business support agencies (external cooperation - for example, with business associations or business support agencies). Innovation indicators were measured using the same Likert scale from 1 to 10 .

The final part covered information related to the profile of the enterprise - for how long and in which industry it had operated, how many employees and what annual turnover it had, where it was located and whether the enterprise had significant foreign investment in its equity capital.

The questionnaire was distributed amongst senior managers of randomly selected economically active SMEs in Latvia. In line with the European Union (EU) definition given in the European Commission Recommendation of 6 May 2003 concerning the definition of micro, small and medium-sized enterprises - 2003/361, this study considers SMEs as enterprises, which employ fewer than 250 persons. The fieldwork was conducted by research agency Kantar TNS using computerassisted telephone interviewing method. Interviews were conducted in May and June of 2017 and 477 responses were used for this analysis.

\subsection{Statistical Methods}

Two main variables were used to explore the relationship between ethics and innovation - an independent variable $E B$, which measures ethical behavior, and a dependent variable $O I$, which measures organizational innovation, calculated as an average of the statements concerning organizational innovation. Both variables were measured using the same Likert scale from 1 to 10.

Firstly, normality testing was performed to choose the most appropriate methods for further analysis. The results are displayed in Table 1 and Figures 1-2.

Table 1. $E B$ normality testing

\begin{tabular}{|l|r|r|r|r|r|r|}
\hline & \multicolumn{3}{|c|}{ Kolmogorov-Smirnov $^{\text {a }}$} & \multicolumn{3}{c|}{ Shapiro-Wilk } \\
\cline { 2 - 7 } & Statistic & $\boldsymbol{d} \boldsymbol{f}$ & Sig. & Statistic & $\boldsymbol{d} \boldsymbol{c}$ & \multicolumn{1}{c|}{ Sig. } \\
\hline$E B$ & 0.180 & 477 & 0.000 & 0.882 & 477 & 0.000 \\
\hline
\end{tabular}

${ }^{a}$ Lilliefors significance correction.

Source: authors' calculations. 


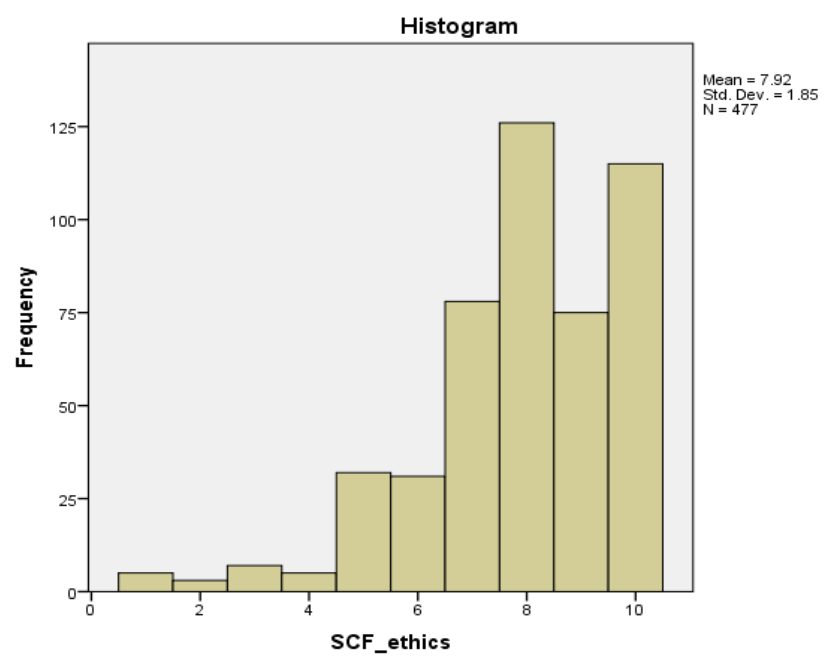

Fig. 1. $E B$ frequency histogram. Source: authors' calculations.

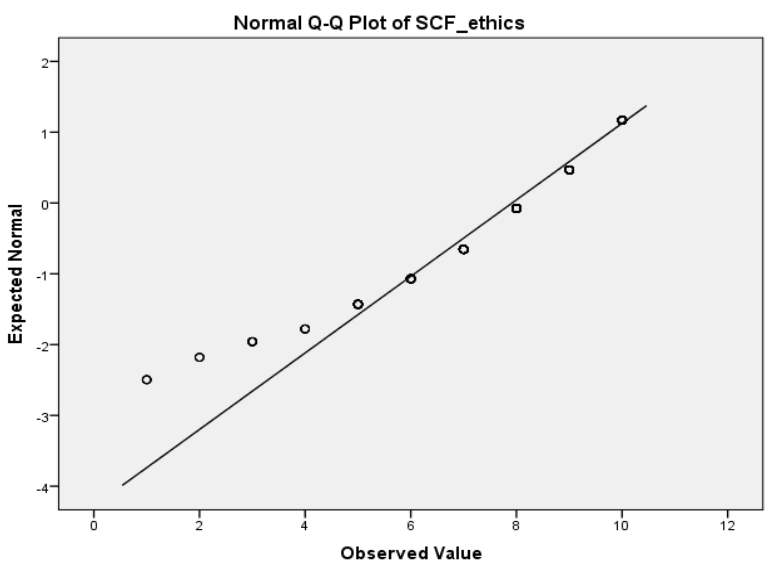

Fig. 2. $E B$ Q-Q plot. Source: authors' calculations.

As these analyses demonstrate, $E B$ is not normally distributed - in most of the surveyed enterprises senior managers agreed that employees follow the principles of business ethics in their work. In this regard, we used non-parametric techniques in further analysis, and simple regression was used just to assess the correlation or the association degree between $E B$ and $O I$, without performing statistical inference about the regression coefficients.

\subsection{Contingency Tables}

Contingency tables can be used as a non-parametric technique to test independence between $E B$ and $O I$. We assumed independence between both variables as the null hypothesis and some degree of association as the alternative hypothesis. We dichotomized $E B$ and $O I$ for the tables in the same way considering values not exceeding 5 as a negative case and other values as a positive case. 
Then we calculated Pearson $\chi^{2}$ statistics to test the null hypothesis against the alternative hypothesis. Pearson $\chi^{2}$ test statistics is obtained by comparing the observed cell counts with the expected figure that should be in cells in case of independence between the variables. The differences are squared to transform negative values and relativized by dividing figures by the expected cell count. The last step is to accrue all figures for all cells of the contingency table. Pearson $\chi^{2}$ behaves in a probability as a Pearson $\chi^{2}$ probability distribution of $k-1$ degrees of freedom (being $k$ the number of categories for the variable with less categories) (Peck, Olsen \& Devore, 2016):

$$
\chi^{2}=\sum_{\text {All cells }} \frac{(\text { observed cell account }- \text { expected cell account })^{2}}{\text { expected cell account }}
$$

The decision whether to reject the null hypothesis is made by considering critical values for the decided significance level.

\subsection{Simple Regression Through the Ordinary Least Squares Method}

In case of rejecting the null hypothesis of independence, the degree of association could be tested by a simple regression analysis using the ordinary least squares method. This technique minimizes the square distance between the cloud of data and the regression function proposed by the model and obtains the value of each coefficient of the explaining variables (Gujarati, 2009).

To minimize the length of all data error bars (unobserved or $u_{i}$ ), this technique solves normal equations (derivatives of the quadratic mean deviations with respect to every parameter or the regression coefficient) for calculating the values of the regression coefficients for every predictor and for the intercept of the following regression line. See, for instance, (Wackerly, 2008):

$$
\widehat{Y}_{\imath}=\widehat{\beta_{0}}+\widehat{\beta_{1}} X_{i}
$$

Being, then, the Quadratic Mean Deviations Function:

$$
Q D F=\sum_{i=1}^{n}\left(y_{i}-\widehat{y}_{l}\right)^{2}=\sum_{i=1}^{n}\left[y_{i}-\left(\widehat{\beta_{0}}+\widehat{\beta_{1}} X_{i}\right)\right]^{2},
$$

where

QDF - Quadratic Deviations Function;

$\widehat{y}_{l}$ - predicted value for the dependent variable corresponding to $i$ th participant;

$y_{i}$ - observed value for the dependent variable corresponding to $i$ th participant;

$\widehat{\beta_{0}}-$ intercept of the regression line;

$\widehat{\beta_{1}}-$ slope of the regression line.

Generalizing this method to any curvilinear relationship between independent and dependent variables the goodness of fit of the regression curve can be obtained through the determination coefficient, as stated by (Gujarati, 2009):

$$
R^{2}=\frac{\sum_{i=1}^{n}\left(\widehat{y}_{l}-\bar{y}\right)^{2}}{\sum_{i=1}^{n}\left(y_{i}-\bar{y}\right)^{2}}
$$

which multiplied by 100 represents the percentage of common causes between the independent and dependent variables. 


\subsection{Analysis by Factors and Kruskal-Wallis Test}

The initial analysis by factors can be performed by examining charts displaying incidence of factors (categorical variables) over a quantitative variable. Such charts can be obtained, for instance, by R programming language using the library ggplot2 and the following syntax (Fig. 3):

ggplot (InnoDBbyRMF, aes(x = Avgdep, fill = Pregion) $)+$ geom_bar( $)+$ labs(x = "OI", y = "COU NT", title = "Count of OI by levels and by Region")

Fig. 3. R syntax for obtaining a bar chart. Source: own design.

A deeper analysis to confirm the influence of factors can be done using Kruskal-Wallis test as a non-parametric alternative to ANOVA. For this test items of groups are ranked from lowest to highest and then computed in a formula to calculate the $H$ test statistics, as indicated in (Mendenhall, 2006):

$$
H=\left[\frac{12}{n(n+1)} \sum_{i=1}^{k} \frac{T_{i}^{2}}{n_{i}}-3(n+1)\right],
$$

where

$n$ - number of observations in the sample;

$k$ - number of groups;

$n_{i}$ - number of observations in the $i$ th group;

$T_{i}-$ rank sum of observations for the $i$ th group.

$H$ test statistics approaches Pearson $X_{k-1}^{2}$ probability distribution, where $k-1$ corresponds to the degrees of freedom of the probability distribution being $\mathrm{k}$ the number of groups, as the groups size increases (for sizes $\geq 5$ ). Decision about rejecting the null hypothesis (independence of populations) is made based on the $p$ values.

\subsection{Wilcoxon Rank Sum Test}

In case of rejecting the null hypothesis for independence with Kruskal-Wallis Test, Wilcoxon Rank Sum Test can be performed as a non-parametric equivalent of the $t$-test for comparing equality of means between two independent populations. Test statistics $(T)$ can be calculated after calculating ranking of groups, which will behave as a known probability distribution as group size increases allowing calculating the critical values and $p$-values:

$$
T=\min \left(T_{i}, T_{i}^{*}\right)
$$

where

$i$ - the group with the smallest sample size;

$T_{i}-$ sum of ranks of observations included in group $i$ ordered from smallest to greatest;

$T_{i}^{*}=\left[n_{1}\left(n_{1}+n_{2}+1\right)-T_{i}\right]-$ sum of ranks of observations included in group $i$ ordered from greatest to smallest.

$T$ reaches normality for groups $>10$, being its expected value and variance: 


$$
\mu_{T}=\frac{n_{1}\left(n_{1}+n_{2}+1\right)}{2}
$$

where

$\mu_{T}$ - expected value or mean for the $T$ statistics;

$n_{1}$ - number of observations or size of the first group;

$n_{2}$ - number of observations or size of the second group;

$$
\sigma_{T}^{2}=\frac{n_{1} n_{2}\left(n_{1}+n_{2}+1\right)}{12},
$$

where

$\sigma_{T}^{2}-$ Variance for the $T$ statistics;

$n_{1}$ - number of observations or size of the first group;

$n_{2}$ - number of observations or size of the second group.

Rejection of the null hypothesis of independence is based on the $p$-values.

\section{RESULTS}

\subsection{Ethical Behavior and Organizational Innovation Performance}

According to the results, over $50 \%$ of the surveyed were micro enterprises, $37.1 \%$ - small enterprises and $12.6 \%$ - medium-sized enterprises. $24.7 \%$ of the enterprises had annual turnover up to EUR $50000,14.7 \%$ - EUR 50001 to EUR 100 000, $23.7 \%$ - EUR 100001 to EUR 500000 and $12.3 \%$ - EUR 500001 to EUR 1000 000, and $24.67 \%$ enterprises - more than 1 million EUR. SMEs were generally well-established in their respective industries - just $2.2 \%$ were new and had been working for 1 to 3 years, $23.8 \%$ - form 4 to 9 years, $43 \%$ - from 10 to 20 years and $31 \%$ - for more than 20 years. The sample included enterprises from all regions of Latvia - $28.6 \%$ were based in Riga, $23.2 \%$ - in large cities, $23.3 \%$ - in other cities and $24.8 \%$ - in the rural areas. The sample covered diverse industries, with $6 \%$ of the SMEs working in agriculture, $25 \%$-in manufacturing, $22 \%$ - in trade, $26 \%$ - in services and $29 \%$ - in other, also primarily service related industries.

Microenterprises reported the highest level of EB rated on average 8.32 on the scale of 10 in comparison to small enterprises rated on average 7.53 and mediumsized enterprises -7.49 . In terms of turnover, smaller enterprises with the annual turnover up to EUR 50000 and the largest enterprises with the annual turnover of more than 5 million EUR reported the most ethical behavior, which gradually lowered for medium levels of turnover. SMEs from Riga reported higher levels of $E B$ (on average 8.30 out of 10), followed by SMEs from small cities (8.20), from other larger cities (7.79) and rural areas (7.39). SMEs in service sectors reported higher levels of $E B$ (8.07 to 8.35) in comparison to agriculture SMEs (6.94) and manufacturing SMEs (7.23).

When looking at the $O I$, medium-sized enterprises were on average the most innovative - rated on average 5.77 on the scale of 10 , followed by small enterprises (5.66), while microenterprises were the least innovative (4.85). 


\subsection{Association Between $E B$ and $O I$}

All results obtained through various types of analysis indicate that there is an association between $E B$ and $O I$. Firstly, the results of contingency table indicate an association (Table 2) - if the variables were independent, the numbers for different cases in the table would be equal.

Table 2. Contingency table for dichotomized $E B$ and $O I(n=477)$

\begin{tabular}{|l|l|c|c|c|}
\hline \multicolumn{2}{|c|}{} & \multicolumn{2}{c|}{ UNBIASED_OI_dicot } & \multirow{2}{*}{} \\
\cline { 3 - 5 } \multicolumn{2}{|c|}{} & Negative & Positive & Total \\
\hline \multirow{2}{*}{ EB_dicot } & Negative & 37 & 15 & 52 \\
\cline { 2 - 5 } & Positive & 227 & 198 & 425 \\
\hline \multicolumn{2}{|c|}{ Total } & 264 & 213 & 477 \\
\hline
\end{tabular}

Source: authors' calculation.

Secondly, $p$-values obtained by Chi-Square tests are lower than the set significance level of 0.05 (Table 3). Fisher's exact test is not required since all values in the contingency table $>5$ (the expected values equal the total number of observations multiplied by their probabilities).

Table 3. Chi-square test results for independence between $E B$ and $O I(n=477)$

\begin{tabular}{|l|c|c|c|c|c|}
\hline & Value & Df & $\begin{array}{c}\text { Asymptotic } \\
\text { Significance } \\
\text { (2-sided) }\end{array}$ & $\begin{array}{c}\text { Exact Sig. } \\
\text { (2-sided) }\end{array}$ & $\begin{array}{c}\text { Exact Sig. } \\
\text { (1-sided) }\end{array}$ \\
\hline Pearson Chi-Square & $5.901^{\mathrm{a}}$ & 1 & 0.015 & & \\
\hline Continuity Correction $^{\mathrm{b}}$ & 5.205 & 1 & 0.023 & & \\
\hline Likelihood Ratio $^{\text {2inger }}$ & 6.124 & 1 & 0.013 & & \\
\hline Fisher's Exact Test & & & & 0.018 & 0.010 \\
\hline Linear-by-Linear Association & 5.889 & 1 & 0.015 & & \\
\hline
\end{tabular}

a 0 cells $(0.0 \%)$ have expected count less than 5. The minimum expected count is 23.22 .

${ }^{\mathrm{b}}$ Computed only for a $2 \times 2$ table.

Source: authors' calculations.

Finally, various regression functions were explored to explain the relation between EB and $O I$. This study concludes that Order 6 Polynomial Regression Function fits the data cloud the best, although correlation coefficients are rather weak (Fig. 4). 


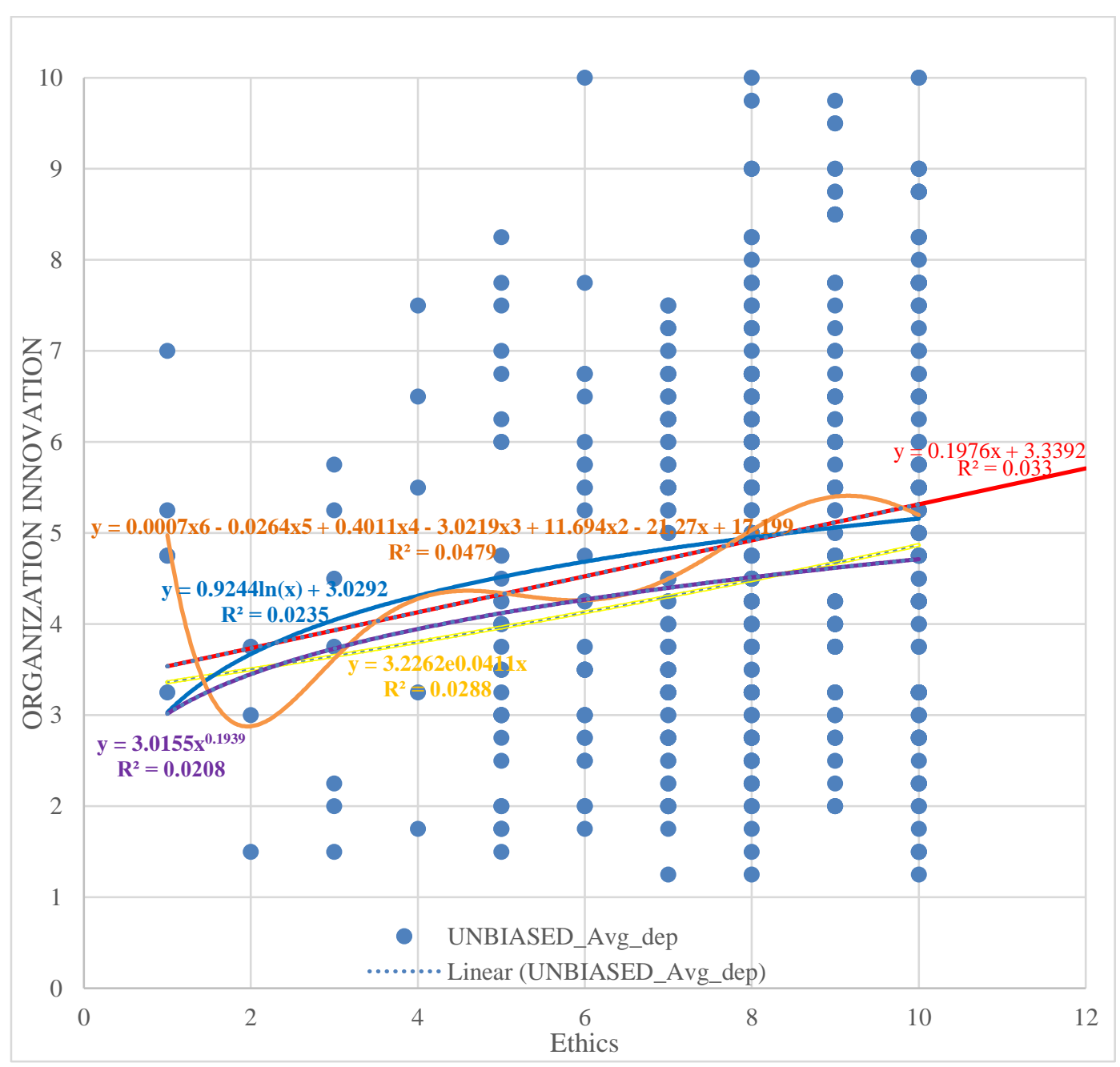

Fig. 4. Regression functions adjusted to the data cloud. Source: authors' calculations.

\subsection{Analysis of $O I$ by Factors}

Following confirming a general association between $E B$ and $O I$, this study assessed the influence of various factors, such as the number of years enterprise had been operating, the number of employees, the location and the level of foreign capital it had over the values of $O I$.

The initial analysis can be done by visualization techniques using $R$ bar chartsan example analysis of whether the region affects $O I$ is displayed in Fig. 5. The layer structure of the region factor at different $O I$ levels indicates that the region influences $O I$.

The influence of the factors was further analyzed by Kruskal-Wallis test, and, in case differences between groups existed, the pairs were compared by Wilcoxon Rank Sum Test to specify the nature of the differences. Finally, strength of the association between $E B$ and $O I$ was assessed by levels of factors. 


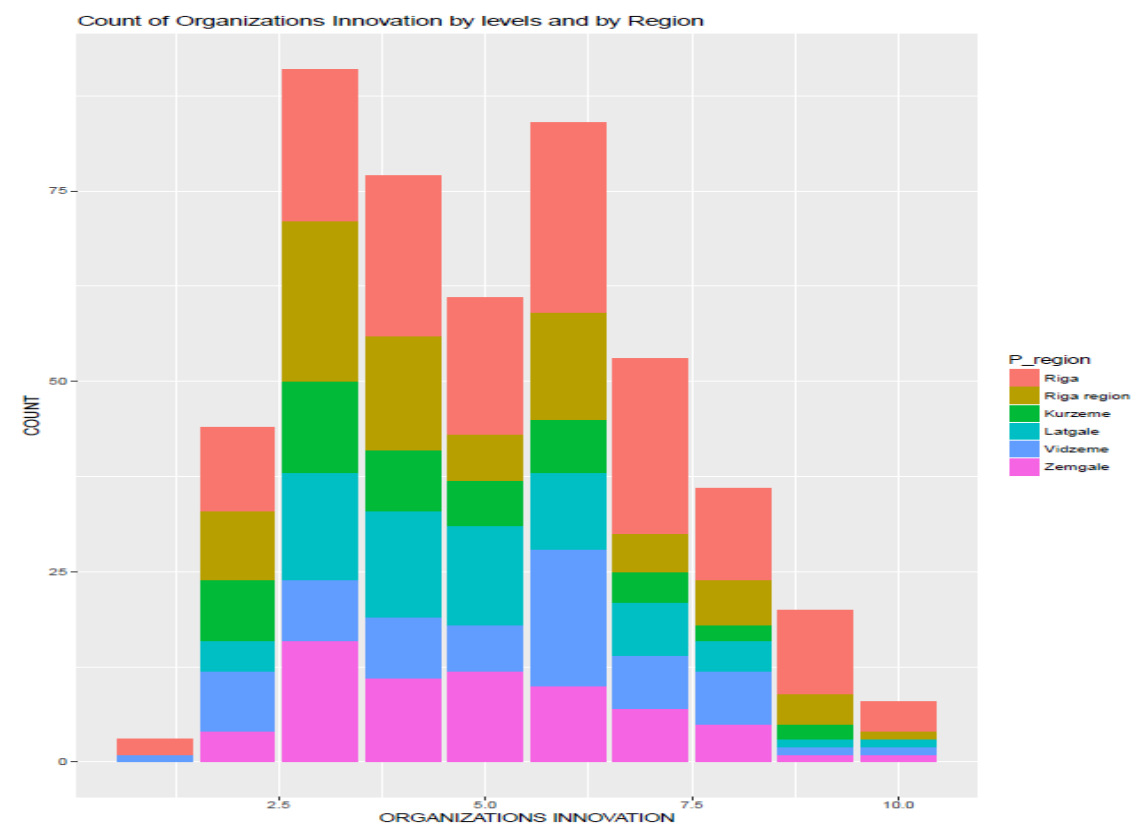

Fig. 5. Bar chart of $O I$ by region obtained through $\mathrm{R}$ programming language. Source: authors' calculation.

The results of these tests are summarized in Table 4 .

Table 4. Summary of the Results by Factor

\begin{tabular}{|c|c|c|c|c|c|c|c|}
\hline 莺 & 苞 & 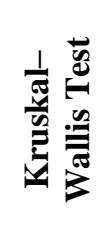 & 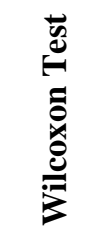 & & 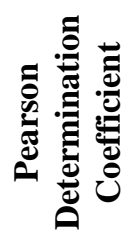 & $z$ & 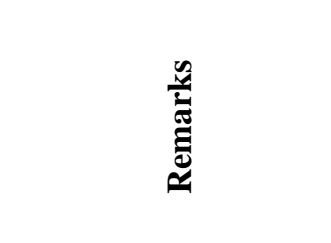 \\
\hline \multirow{4}{*}{ 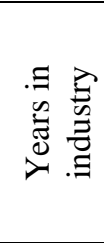 } & $1-3$ & \multirow{4}{*}{0.361} & \multirow{4}{*}{-} & \multirow{4}{*}{ Cubic } & 0.147 & 13 & \multirow{4}{*}{$\begin{array}{l}\text { The factor does not } \\
\text { influence } O I \text {. } \\
\text { Correlation between } \\
E B \text { and } O I \text { does not } \\
\text { show any clear pattern } \\
\text { by factor levels }\end{array}$} \\
\hline & $4-9$ & & & & 0.081 & 122 & \\
\hline & $10-20$ & & & & 0.017 & 200 & \\
\hline & $>20$ & & & & 0.086 & 142 & \\
\hline \multirow{3}{*}{ 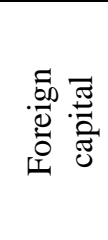 } & $\begin{array}{c}\text { Yes, } \\
\geq 50 \%\end{array}$ & \multirow{3}{*}{0.006} & \multirow{3}{*}{$(1-3)$} & Cubic & 0.272 & 22 & \multirow{3}{*}{$\begin{array}{l}\text { The factor influences } \\
O I \text {. Correlation } \\
\text { between } E B \text { and } O I \\
\text { does not show any } \\
\text { clear pattern by levels } \\
\text { of this factor }\end{array}$} \\
\hline & $\begin{array}{l}\text { Yes, } \\
<50 \% \\
\end{array}$ & & & $\begin{array}{c}\text { Quadratic, } \\
\text { Cubic }\end{array}$ & 0.930 & 4 & \\
\hline & No & & & Cubic & 0.032 & 450 & \\
\hline \multirow{3}{*}{ 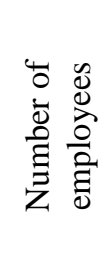 } & $1-9$ & \multirow{3}{*}{0.000} & \multirow{3}{*}{$\begin{array}{l}(1-2), \\
(1-3)\end{array}$} & \multirow{3}{*}{ Cubic } & 0.078 & 184 & \multirow{3}{*}{$\begin{array}{l}\text { The factor influences } \\
O I \text {. Correlation } \\
\text { between } E B \text { and } O I \\
\text { shows that medium- } \\
\text { sized enterprises have } \\
\text { stronger } E B-O I \\
\text { association }\end{array}$} \\
\hline & $10-49$ & & & & 0.036 & 229 & \\
\hline & $50-249$ & & & & 0.244 & 64 & \\
\hline
\end{tabular}




\begin{tabular}{|c|c|c|c|c|c|c|c|}
\hline \multirow{4}{*}{ 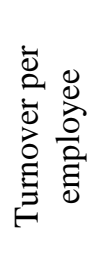 } & Low & \multirow{4}{*}{0.002} & \multirow{4}{*}{$\begin{array}{l}(1-3) \\
(1-4)\end{array}$} & Cubic & 0.053 & 160 & \multirow{4}{*}{$\begin{array}{l}\text { The factor influences } \\
O I \text {. Correlation } \\
\text { between } E B \text { and } O I \\
\text { shows that enterprises } \\
\text { with higher turnover } \\
\text { have slightly stronger } \\
E B-O I \text { association }\end{array}$} \\
\hline & Medium & & & Cubic & 0.036 & 86 & \\
\hline & High & & & $\begin{array}{l}\text { Quadratic, } \\
\text { Cubic }\end{array}$ & 0.091 & 115 & \\
\hline & $\begin{array}{l}\text { Very } \\
\text { High }\end{array}$ & & & Cubic & 0.052 & 116 & \\
\hline \multirow{4}{*}{ 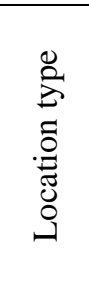 } & Riga & \multirow{4}{*}{0.022} & \multirow{4}{*}{$\begin{array}{l}(1-2), \\
(1-3), \\
(1-4)\end{array}$} & \multirow{4}{*}{ Cubic } & 0.081 & 147 & \multirow{4}{*}{$\begin{array}{l}\text { The factor influences } \\
O I \text {. Correlation } \\
\text { between } E B \text { and } O I \\
\text { shows that enterprises } \\
\text { located in Riga have } \\
\text { slightly higher } E B-O I \\
\text { association }\end{array}$} \\
\hline & $\begin{array}{c}\text { Large } \\
\text { city }\end{array}$ & & & & 0.058 & 107 & \\
\hline & $\begin{array}{c}\text { Small } \\
\text { city }\end{array}$ & & & & 0.015 & 109 & \\
\hline & Rural & & & & 0.068 & 114 & \\
\hline \multirow{6}{*}{ 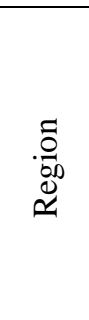 } & Riga & \multirow{6}{*}{0.024} & \multirow{6}{*}{$\begin{array}{c}(1-2) \\
(1-3)\end{array}$} & \multirow{6}{*}{ Cubic } & 0.081 & 147 & \multirow{6}{*}{$\begin{array}{l}\text { The factor influences } \\
O I \text {. Correlation } \\
\text { between } E B \text { and } O I \\
\text { shows that SMEs from } \\
\text { Latgale, Vidzeme and } \\
\text { Riga have slightly } \\
\text { higher } E B-O I \\
\text { association }\end{array}$} \\
\hline & Riga reg. & & & & 0.008 & 81 & \\
\hline & Kurzeme & & & & 0.026 & 49 & \\
\hline & Latgale & & & & 0.100 & 68 & \\
\hline & Vidzeme & & & & 0.094 & 65 & \\
\hline & Zemgale & & & & 0.016 & 67 & \\
\hline
\end{tabular}

Source: authors' calculations.

\section{CONCLUSION, LIMITATIONS AND FURTHER RESEARCH}

SMEs in Latvia were surveyed to assess their approach towards $E B$ and $O I$ performance. Most of the surveyed enterprises believed that their employees follow principles of ethics in their work. $E B$ was the highest in microenterprises, the smallest and the largest enterprises in terms of turnover, enterprises from Riga or from small cities and service enterprises. OI performance, on the other hand, was the highest in medium-sized enterprises, enterprises operating in Riga and enterprises with significant foreign capital in their equity capital.

Assessing the association between $E B$ and $O I$ with various statistical techniques, we conclude that better $E B$ indicators increase the $O I$ performance. Thus the research hypothesis - enterprises, where employees follow the principles of business ethics in their work, display a better organizational innovation performance - can be confirmed. Influence of various factors, such as industry, the size and location of operation and the level of foreign investment, were also assessed, concluding that the size of the enterprise is the most significant factor affecting the relationship between $E B$ and $O I$.

This study has some limitations. Firstly, even though the variables used in the research were quantitative, they were not continuous. Additionally, the scale includes integer numbers from 1 to 10 , thus it is more complicated to use the variables in the regression analysis. It could be addressed by introducing dummy variables for each level used in the scale, however then the sample size would have to be adequate to sustain that many additional variables in regression.

Secondly, we acknowledge that correlation does not mean causation, and there could be other factor(s) influencing both variables affecting the results, so there 
could be a misspecification error (Wassertheil-Smoller \& Smoller, 2015). This study assesses the relationship between ethical behavior and organizational innovation, and while previous research has also linked ethical behavior with performance and various aspects related to innovation, we cannot fully exclude a possibility that another organizational factor outside the scope of this study is influencing both ethical behavior and organizational innovation. This could be tested by defining possible third factors and testing, whether they are correlated with the error term of the model. In practice, organizations are complex systems where many aspects affect each other, so it might not be practically possible to test and exclude the influence of such third factors.

In conclusion, the study has confirmed that more ethical behavior could lead to better organizational innovation performance. It proposes the insights that contribute to theoretical and practical discussions on fostering small businesses innovation in small economies.

\section{ACKNOWLEDGMENT}

This work was supported by Eigits Dāvis Timermanis scholarship and the University of Latvia Foundation.

\section{REFERENCES}

Acs, Z. J., \& Audretsch, D. B. (1988). Innovation in large and small firms: an empirical analysis. American Economic Review, 78(4), 678-690.

Armbruster, H., Bikfalvi, B., Kinkel, S., \& Lay, G. (2008). Organizational innovation: The challenge of measuring non-technical innovation in large-scale surveys. Technovation, 28(10), 644-657. https://doi.org/10.1016/j.technovation.2008.03.003

Boatright, J. R. (1997). Ethics and the conduct of business. Upper Saddle River: Prentice-Hall.

Damanpour, F. (1987). The adoption of technological, administrative and ancillary innovations: impact of organizational factors. Journal of Management, 13(4), 675-688.

Drucker, P. F. (1985). Innovation and Entrepreneurship, R: Butterworth \& Heinemann, London.

Eurostat. (2017). Small and Medium-Sized Enterprises (SMES). Retrieved September 20, 2017, from: http://ec.europa.eu/eurostat/web/structural-business-statistics/structural-business-statistics/sme

European Commission (2003). Commission Recommendation of 6 May 2003 concerning the definition of micro, small and medium-sized enterprises C (2003) 1422). Retrieved from https://publications.europa.eu/en/publication-detail/-/publication/6ca8d655-126b-4a42-ada4e9058fa45155/language-en

Fisher, C. M., \& Lovell, A. (2009). Business ethics and values: Individual, corporate and international perspectives. Pearson education.

Gujarati, D. N. (2009). Basic econometrics. McGraw-Hill/Irwin, Inc.

Hamel, G. (2000) Leading the revolution, Harvard Business School Press, Boston, 364 p.

Hofstede, G. H., Hofstede, G. J., \& Minkov, M. (2010). Cultures and Organizations: Software of the Mind. New York: McGraw-Hill.

Hosmer, L. (1995). Trust: The Connecting Link between Organizational Theory and Philosophical Ethics. The Academy of Management Review, 20(2), 379-403. Retrieved from http://www.jstor.org/stable/258851

Kline, S.J. \& Rosenberg, N. (1986). The positive sum strategy: Harnessing technology for economic growth. An overview of innovation, 275-305. Retrieved from https://www.nap.edu/read/612/chapter/18\#304

Knut, I. J., \& Zsolnai, L. (2014). Ethics of social innovation. Society and Business Review, 9(2), 186-194. https://doi.org/10.1108/SBR-11-2013-0076

Mendenhall, W. (2006). Introduction to Probability and Statistics, 13th ed. Cengage Learning.

Nooteboom, B. (1994). Innovation and diffusion in small firms: theory and evidence. Small Business Economics, 6(5), 327-347.

OECD-Eurostat - Oslo Manual. (2005). Retrieved September 21, 2017, from http://www.oecdilibrary.org/science-and-technology/oslo-manual_9789264013100-en 
Peck, R., Olsen, C., \& Devore, J. L. (2016). Introduction to Statistics and Data Analysis, Fifth Edition. Boston: Cengage Learning.

Porter, M. E. (1980). Competitive Strategy: Techniques for Analyzing Industries and Competitors. Free Press, New York.

Schumpeter, J. (1934). The Theory of Economic Development, Harvard University Press, Cambridge, Massachusetts.

Treviño, L. K., Weaver, G. R. \& Reynolds, S.J. (2006). Behavioral ethics in organizations: A review. Journal of Management, 32(6), 951-990. https://doi.org/10.1177/0149206306294258

Wackerly, D. M. (2008). Mathematical statistics with applications, 7th ed. Thomson/Brooks-Cole.

Wassertheil-Smoller, S., \& Smoller, J. (2015). Biostatistics and Epidemiology A Primer for Health and Biomedical Professionals. Fourth Edition. New York: Springer Science+ Business Media.

Womack, J., \& Jones, D. (1990). The Machine That Changed the World: The Story of Lean Production. Harper Perennial, New York.

\section{AUTHORS' SHORT BIOGRAPHIES}

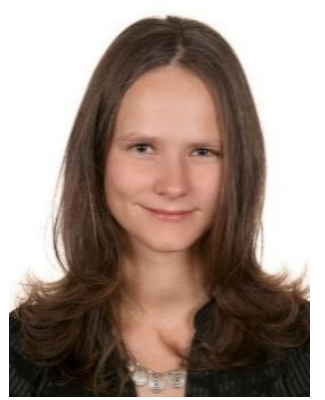

Madara Apsalone is a Ph.D. student of Management Science (Business Administration) at the University of Latvia, Faculty of Business, Management and Economics in Riga, Latvia. She received MS in International Business and Economics from the University of Latvia, Riga, Latvia in 2011 and MBA in Global Management with distinction from Thunderbird School of Global Management, Phoenix, Arizona, USA, in 2010. She is also a PMI certified Project Management Professional (PMP). Her expertise is global leadership and strategy; she has an extensive experience working with European Union Policy and International Affairs for the Latvian government, global business at the Investment and Development Agency of Latvia and international education at the Erasmus Student Network - the largest international student association in Europe. Since fall 2016 she works for Philip Morris as the Corporate Affairs Manager of Latvia. She is a researcher in the project "Involvement of the society in social innovation for providing sustainable development of Latvia," conducted within the National Research Program "Economic Transformation, Smart Growth, Governance and Legal Framework for the State and Society for Sustainable Development - a New Approach to the Creation of a Sustainable Learning Community (EKOSOC-LV)". Her research interests include sociocultural factors, organizational competitiveness, innovation and business ethics.

E-mail: madara.apsalone@gmail.com

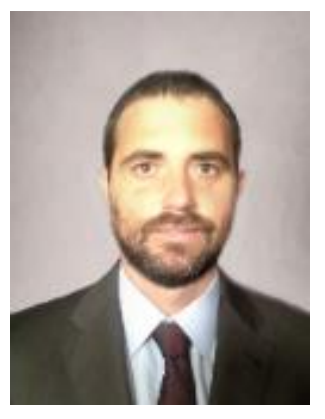

Ricardo Martín Flores studied Business Administration at Complutense University with specialization in Actuarial and Financial Sciences. He has got a Master in Statistics and Operational Research from that University. He has been certified as "Expert in Coaching" as well. He is currently working on his $\mathrm{PhD}$ while transferring his Dissertation from the University of Las Palmas de Gran Canaria to the University of Latvia. His expertise is Statistics and Excel, which has been obtained at Riga Business School, where he also teaches Spanish as a Foreign Language. His background also includes actuarial and financial matters, which were developed in insurance business, where he contributed to development of a mathematical model of Assets and Liabilities as a member of the Risk Management Team of AXA insurance company in Madrid. His previous experience as a researcher was under Quantitative Methods Department in Universidad de las Palmas de Gran Canaria where he researched under the Bayesian Statistics Research Line developing Poisson Processes for the incidence of Spinal Cord Injury in the Island of Gran Canaria. He was also cooperating as a freelancer with Instituto de Salud Carlos III de Madrid in the field of Biostatistics. His research interests include Innovation Ecosystems and Machine Learning.

E-mail: ricardo.flores@rbs.lv 